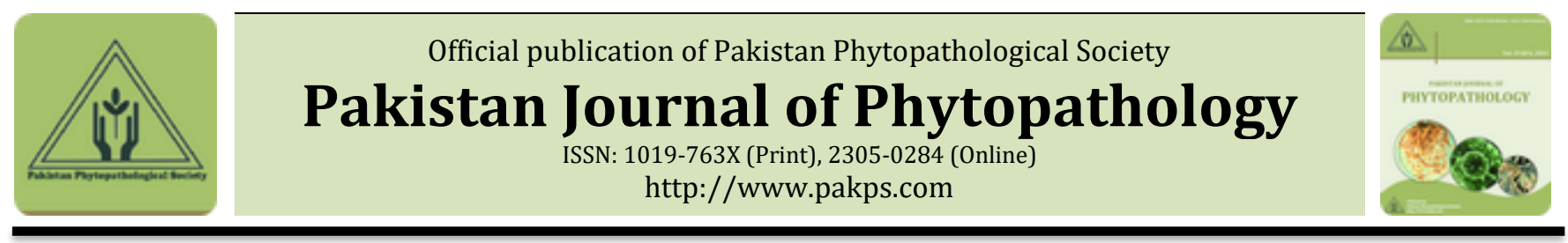

\title{
SURVEY, VARIETAL REACTION AND CHEMICAL CONTROL OF STRAWBERRY CHARCOAL ROT IN EGYPT
}

\author{
Ramadan A. Bakr*, Abdullah S. Hamad \\ Agricultural Botany Department, Faculty of Agriculture, Menoufia University, Egypt.
}

\section{A B S T R A C T}

A survey was carried out to know the occurrence of charcoal rot disease of strawberry caused by Macrophomina phaseolina in different selected locations representing different soil types during the growing season of strawberry in Badr and Kom Hamada Districts in El-Behira governorate, Egypt. Also, the effect of five chemical fungicides at five concentrations was determined in vitro and in vivo experiments against M. phaseolina compared to the control. A total of 69 strawberry samples collected from farmer's fields. Disease incidence (DI) and percentage of disease incidence (PDI) and disease index were recorded. Results revealed that percentage of disease incidence varies among the surveyed locations. Macrophomina phaseolina isolates M3 and M4 were the most destructive isolates. Results indicate that the selected Four strawberry cultivars showed different susceptibility to charcoal rot and Festival was the high susceptible cultivar. Our findings revealed that at $100 \mathrm{ppm}$ concentration the most of the fungicides used inhibited the M. phaseolina mycelium growth, however the higher rate was recorded with Sendo by $91.95 \%$ followed by $91.12 \%$ in Rhizolex-T and the least rate was recorded with Ridomil gold plus by $31.67 \%$. At 200 ppm Rhizolex-T gave the highest inhibition by $96.67 \%$, followed by Sendo and Sandcur by 95.96 and $95.00 \%$ respectively while Ridomil gold plus gave the least inhibition rate by $43.06 \%$.Results illustrated that use of fungicides markedly increased the survival of strawberry plants. The highest plant survival percentage was recorded with Rhizolex-T by $80 \%$ followed Sendo by $60 \%$, while least plants survival percentage was recorded with Ridomil gold plus by $10 \%$ compared with infected untreated control.

Keywords: Distribution, Macrophomina phaseolin, Management, Strawberry.

\section{INTRODUCTION}

Strawberry (Fragaria ananassa Duch.) is an important crop that belongs to family Rosaceae. In the last five years, it put itself as one of the most important economic export crop in Egypt. In 2014, Egypt ranked as $4^{\text {th }}$ globally in term of strawberry quantity and quality. Fresh strawberries are cultivated in three main growing governorates in Egypt: El-Behira, Qalubia and Ismailia. In 2016the cultivated area of strawberry was recorded as 9985 ha producing 4654958 tons (FAO, 2016). Strawberry production can be limited by several soilborne diseases (Porras et al., 2007).

\section{Submitted: Apri 25, 2019 \\ Revised: June 09, 2019 \\ Accepted for Publication: June 11, 2019 \\ * Corresponding Author: \\ Email: ramadanbaker82@yahoo.com}

(C) 2017 Pak. J. Phytopathol. All rights reserved.
In Egypt, strawberry is infected by numerous pathogens that lead to its destruction. A huge number of fungal pathogens has been found and isolated from crown and/or root of strawberry including Cylindrocarpon destructans, Rhizoctonia solani, Fusarium oxysporum, Pythium ultimum, Phytophthora cactorum, Phoma exigua and Macrophomina phaseolina( Fang et al., 2011a; carter,2016).Charcoal rot in strawberry caused by $M$. phaseolina, is one the most dangerous diseases that infect strawberry is leading to their destruction and becoming problematic in Egypt and worldwide, expecting to be an emerging disease after the phase-out of methyl bromide application (Aviles et al., 2008). Charcoal rot was recorded in strawberry-growing farms of other countries such as:Turkey (Benlioglu et al., 2004),United States (Mertely et al., 2005), Greece (Tjamos et al., 2006),Spain (Aviles et al., 2008),Italy (Angelini and Faedi, 2010), Argentina (Baino et al., 
2011); Iran(Sharifi and Mahdavi, 2012)and Australia (Golzar et al., 2007; Hutton et al.,2013).

Plants affected by charcoal rot suffer from wilting, stunting, drying and death of older leaves often central youngest leaves remaining green and alive. Finally, plants collapsed and die, especially if the plants are exposed to environmental stresses or were bearing a heavy load of fruit. Crowns showed that cortex and internal vascular tissues were dark brown to orange (Mertely et al., 2005; Aviles et al., 2008, Koike et al., 2013). There are many limitation of the charcoal rot control related to the pathogen such as survives and great longevity of the microsclerotia large number in the soil and infected plant debris which resilient resistant structures that allow the fungus to persist in fallow fields for longtime up to15 years (Baird et al., 2003).

Also negligence of the crop rotation in the strawberry grown area or cultivated one of the wide host range susceptible crops exceeds over 75 plant families including di-and mono-cotyledons (Dhingra and Sinclair,1978) and highly competitive saprophytic ability (Su et al., 2001; Zveibil et al., 2012). Methyl bromide (MB) was considered as the most successive option for $M$. phaseolina control but now there is variety of limitation on its use. Different methods were tested for management of charcoal rot of strawberry without MB. Solarization, soil organic amendment, compost and manures were used as eco-friendly control methods instead of chemical fungicides but this will be acceptable economically when it keeps the fungus population at low level (Chamorro et al., 2015). Resistant varieties were recommended for high strawberry production and there are different Percentage of Disease Incidence (PDI)

Data regarding the soil type in which the crop is grown and the variety of strawberry cultivated was also recorded in the respective surveyed fields.

Isolation, purification and Identification of the causal organism: Naturally infected strawberry plants showing charcoal rot symptoms were collected from different areas of strawberry growing in ElBehira governorate. Plants samples were carefully brought to the laboratory and processed immediately or kept in a refrigerator for further work. Strawberry roots and crown of diseased plants were cut to small pieces, washed thoroughly with running tap water to remove any adhering soil particles, surface sterilized strawberry varieties in Egypt, but unfortunately there is a limited data on resistance of strawberry to the charcoal rot disease. Little previous research reported some differential response between several genotypes to M. phaseolina infection (Koike et al., 2013; Fang et al., 2011; Sanchez et al., 2016).In Egypt, there are few fungicides registered for charcoal rot in strawberry and for the consideration of losses and importance of the disease. Thus, it is important to evaluate commercial fungicides and their potency for controlling $M$. phaseolina.

Therefore, the present study was conducted to: 1) survey the charcoal rot disease in different locations in El-Behira governorate in Egypt. 2) Pathogenicity with different M. phaseolina isolates, 3) Susceptibility of some commercial strawberry varieties and 4) evaluate the efficacy of five commercial chemical fungicides for inhibiting and control M. phaseolina in-vitro and under greenhouse conditions.

\section{MATERIALS AND METHODS}

Survey of charcoal rot disease on strawberry in different locations in El-Behira Governorate: A survey was carried out to test the occurrence of charcoal rot diseaseon strawberry plantation in different locations with a different soil types in Badr and Kom Hamada Districts in El-Behira governorate, Egypt. Sixty-Nine samples were collected from different locations during growing season of strawberry. Disease incidence (DI) recorded according to the presence or absence of symptoms on the aerial part and crown of strawberry plants. The percentage of disease incidence (PDI) was calculated according to Reznikov et al.,(2018) using the following formula:

$\frac{\text { Number of diseased plants }}{\text { otal Number of observed plants }} \times 100$

by immersing in $0.25 \%$ sodium hypochlorite for 4 minutes, followed by 2 minutes in $70 \%$ ethanol then washed several times by sterilized distilled water then blotted between two sterilized filter papers to removing excess water. Sterilized samples were transferred to Petri dishes containing Potato Dextrose Agar medium (PDA) containing penicillin (50 units/ml), 20 ppm Terramycin, and 40 ppm streptomycin sulfate to avoid bacterial contamination. Plates were incubated in darkness at $28 \pm 2^{\circ} \mathrm{C}$ for 5 days and examined daily for the occurrence of fungal growth. The growing fungi were microscopically examined and then purified using the single spore and 
hyphal tip-technique (Dhingra and Sinclair 1977) and transferred to new PDA plates.

Identification of $\boldsymbol{M}$. phaseolina Isolates: The pure cultures of the isolated fungi were examined microscopically and identified at the Agricultural Botany Department, Faculty of Agriculture, Menoufia University according to their features described by Dhingra and Sinclair (1978) and Watanabe (2010). Pure cultures of the isolates were multiplied and maintained on fresh PDA slants and kept at $5{ }^{\circ} \mathrm{c}$ for further studies.

Pathogenicity test: Seven representative isolates of M. phaseolina of different localities were evaluated for their pathogenicity to the commercially grown susceptible strawberry cultivar Festival. Inoculum were prepared using barley grains medium $(500 \mathrm{ml}$ glass bottles each containing $75 \mathrm{gm}$ barley grains along with $25 \mathrm{gm}$ sand and $100 \mathrm{ml}$ water were autoclaved for 20 minutes at $121^{\circ} \mathrm{C}$ ). Bottles were inoculated and incubated for 15 days at $25^{\circ} \mathrm{C}$. Inoculum at $3 \%$ of soil weight were mixed thoroughly with sterilized sandy soil, and then potted in sterilized clay pots $(30 \mathrm{~cm}$ in diameter).Two strawberry plants were transplanted in $30 \mathrm{~cm}$ dim pots. Pots containing sterilized sandy soil only were used as a control. Five replicates used for each treatment. Plants watered, and agricultural practices done as needed (Gammon, 1972). Thirty days after transplanting, disease incidence was recorded as numbers and percentages of plants initially showing signs of water stress and subsequently collapse and number of survived plants. At the end of the experiment re-isolation of the fungus was done to confirm the association of the fungi with current disease symptoms.

Susceptibility of some strawberry cultivars to $M$. phaseolina: The susceptibility of Four of the most common wide grown cultivars: Festival, winter star, Fortuna and 029 to the most virulent isolate of $M$. phaseolina were evaluated by artificial inoculation under greenhouse conditions. The inoculum were prepared using barley grains medium as above. Plants transplanted in pots filled with soil free of inoculum served as control. Ten replicates were used for each particular treatment. Plants were watered and

$$
\text { Inhibition of Mycelium Growth (IMG) } \%=\frac{A-T}{A} \times 100
$$

$\mathrm{A}=$ Mycelium growth in control, $\mathrm{T}=$ Mycelium growth in treatment. fertilized with a nutrient solution (Gammon, 1972) as needed. Thirty days after transplanting, disease incidence, collapse and number of survival plants was recorded.

Chemical control: In-vitro The experiment was conducted at the Modern Agriculture Company (PICO) lab, Beheria governorate, Egypt. The potency of five different fungicides belonging to diverse chemical groups as illustrated in (Table 1) were used to determine $M$. phaseolina mycelial growth in vitro using PDA medium following the technique described by Tonin et al., (2013). The sensitivity of M. phaseolina mycelium growth to the five fungicides conducted using one strain isolated from strawberry plants crown and roots collected previously in the survey from Beheria governorate, Egypt. The concentrations of $5 \mathrm{ppm}, 10 \mathrm{ppm}, 50 \mathrm{ppm}, 100 \mathrm{ppm}$ and $200 \mathrm{ppm}$ of each fungicide active ingredient were used in the bioassay while, control treatments were substituted with distilled water. One gm of each fungicide was transferred, to a flask containing $1000 \mathrm{~mL}$ final volume of distilled sterile water (stock suspension). For dilution, volumes from the stock suspension according to the needed concentrations adds to 100 mL PDA supplemented with $150 \mathrm{mg}$ of streptomycin sulphate to avoid bacterial contamination growth. Concentrations of each active ingredient were prepared from the stock suspension based on the formula as fallow:

$\mathrm{C} 1 \times \mathrm{V} 1=\mathrm{C} 2 \times \mathrm{V} 2$

$\mathrm{C} 1$ = stock solution concentration.

V1 = volume needed from stock solution.

$\mathrm{C} 2$ = desired final concentration.

$\mathrm{V} 2$ = desired volume for the final solution.

Then flasks containing PDA gently shaken and the medium poured into sterilized $90 \mathrm{~mm}$ Petri dishes. Then $5.0 \mathrm{~mm}$ diameter disks of seven days mycelial growth M. phaseolina were cultured in the center of each poured poisoned PDA dish. Each treatment repeated four times. Then plates incubated at $27 \pm 2^{\circ} \mathrm{C}$ and growth was observed on daily basis. When the control plates covered by fungal mycelium, the mycelium growth of M. phaseolina was measured and Inhibition of mycelial growth was calculated using the following formula: 
Table 1. Trade name, active ingredients and chemical group of used Fungicides.

\begin{tabular}{cccc}
\hline Trade name & Active Ingredient (AI) & Chemical group & Used dose \\
\hline Sendo & Carbendazim 50\% & Benzimidazol & $1.0 \mathrm{~g} / \mathrm{L}$ \\
Moncut & Flutolanil 25\% & Carboxamide & $2.5 \mathrm{~g} / \mathrm{L}$ \\
Sand Cure & Mancozeb 64\% & Dithiocarbamate & $1.5 \mathrm{~g} / \mathrm{L}$ \\
& + Metalaxyl 8\% & + Phenylamideacylalanine & \\
Rhizolex-T & Chlorlnitro phenyl & $2.0 \mathrm{~g} / \mathrm{L}$ \\
Ridomilgold Plus & Tollofes-methyl & + Dimethyl dithiocarbamate & $2.0 \mathrm{~g} / \mathrm{L}$ \\
\hline
\end{tabular}

Under greenhouse conditions: Five fungicides, i.e., Sendo, Moncut, sand cure, Rhizolex-T and Ridomil gold pluswere evaluated for controlling the M. phaseolina in strawberry cv. Festival. All these fungicides were added as soil drench at dose shown in (Table 1). Ten potted strawberry transplanting were soil drenched with the selected five fungicides concentrations. Plants inoculated by M. phaseolina served as a negative control. The positive control treatment was simply watered. Plants kept in the greenhouse and treatments repeated two weeks in intervals. Plants were irrigated and fertilized regularly. Disease initial symptom, collapse, survival plants and growth parameters were calculated at 30 day after transplant.

\section{STATISTICAL ANALYSIS}

Data was statistically analyzed using a computer costat 6.3 version program. Analysis of variance (ANOVA) was

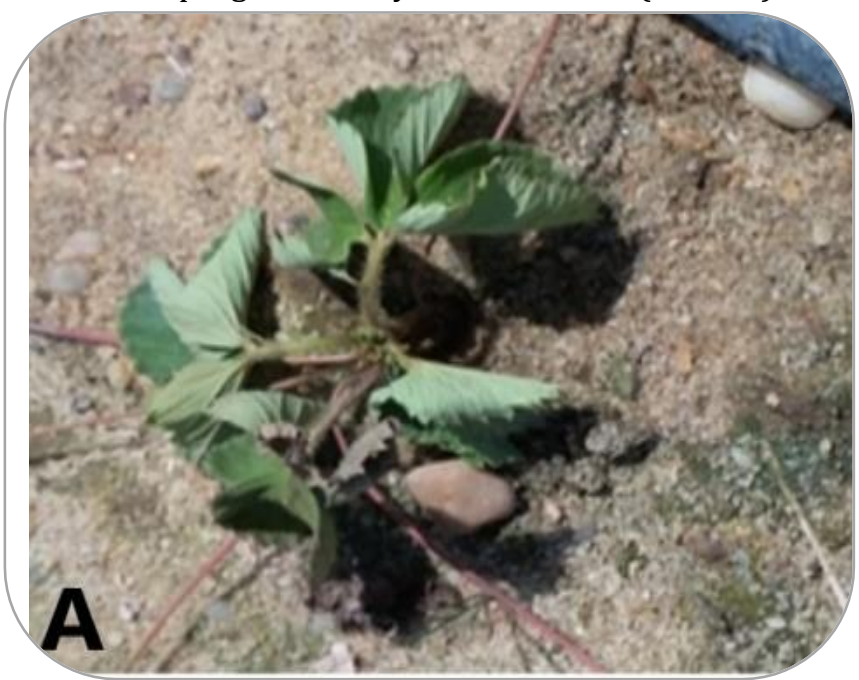

carried out and comparisons of means at the $5 \%$ level of significance.

\section{RESULTS}

Survey of charcoal rot disease in different locations in El-Behira Governorate: Strawberry plants are infected by the charcoal rot when showing the initial symptoms of charcoal rot which usually occur after the plants are well established and begin to produce fruits: the older leaves wilt, turn grayish green in color, and begin to dry up as in (Figure 1A) compared with the healthy plants. As disease progresses, virtually all of the foliage collapsed and dried up with the exception of the central youngest leaves. Histological symptoms of the infected plants showed that plant crowns internal tissues, vascular and cortical tissues were dark brown to orange brown in colour, (Figure 1B).

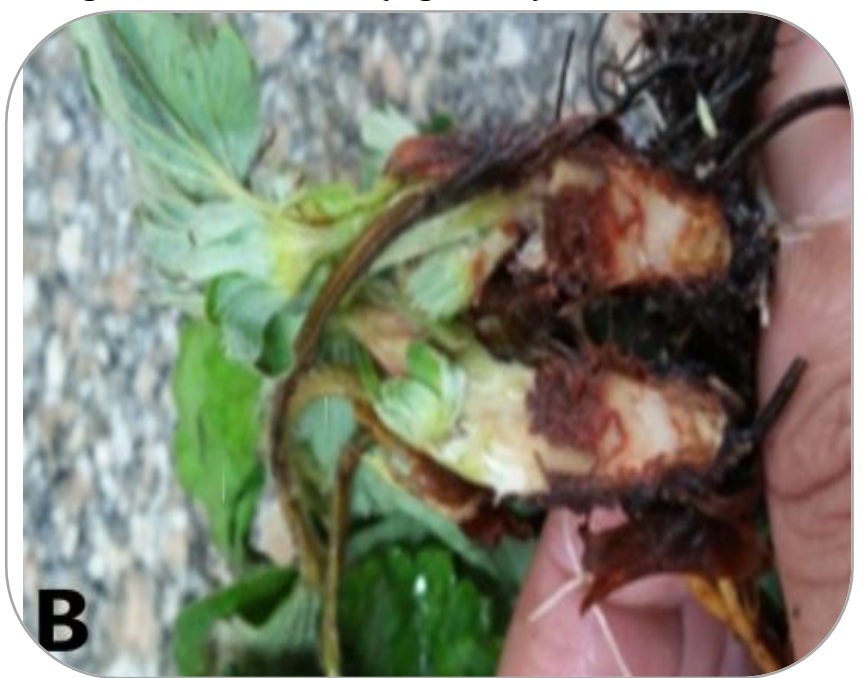

Figure 1. Symptoms of charcoal rot in strawberry infected with M. phaseolina .A) Morphological and Initial symptoms,

B) Strawberry crown tissue show a dark to orange brown discoloration.

The survey was carried out in the selected locations to record the occurrence of charcoal rot disease during the growing season of strawberry. Results revealed that the charcoal rot was recorded in 38 of 69 samples collected from the survey locations in El-Behira Governorate as presented in (Figure 2). The PDI varied up to $30 \%$ from different locations. Disease incidence was recorded in all samples of Festival cultivar in all surveyed locations in both of clay and sandy soil. The most affected locations in Badr was Airport Area and Abdel hamed zedan by $30 \%$ of disease occurrence followed by El Magd location by $28 \%$ while the disease was not recorded in samples from Ali Ebn AbyTaleb and El-Fateeh as shown in (Table 2).The highest PDI were recorded Kom Sherek and Abo El Khawey by $30 \%$ followed by $22 \%$ in Kafr Zyada location in Kom Hamada District as illustrated in (Table 3). 
Table 2. Survey of charcoal rot disease in Badr District, El-Behira Governorate.

\begin{tabular}{|c|c|c|c|c|c|}
\hline Location & No & Cultivar & Soil Type & DI & PDI \\
\hline \multirow[t]{2}{*}{ Ezz El-din } & 1 & Festival & Clay & + & 6 \\
\hline & 2 & Fortuna & Clay & - & 0 \\
\hline El-Khofog & 1 & Festival & Clay & + & 3 \\
\hline \multirow[t]{5}{*}{ Om Saber } & 1 & 029 & Sandy & + & 9 \\
\hline & 2 & Fortuna & Sandy & + & 5 \\
\hline & 3 & Winter Star & Sandy & + & 11 \\
\hline & 4 & Festival & Sandy & + & 14.5 \\
\hline & 5 & Fortuna & Sandy & - & 0 \\
\hline \multirow[t]{2}{*}{ Manshetnaser } & 1 & Festival & Sandy & + & 8 \\
\hline & 2 & Fortuna & Sandy & - & 0 \\
\hline \multirow[t]{3}{*}{ Omar Shahen } & 1 & Festival & Sandy & + & 13.5 \\
\hline & 2 & Winter Star & Sandy & + & 7 \\
\hline & 3 & Fortuna & Sandy & - & 0 \\
\hline \multirow[t]{3}{*}{ Omar Makram } & 1 & Florida & Sandy & + & 11 \\
\hline & 2 & 029 & Sandy & - & 0 \\
\hline & 3 & Fortuna & Sandy & - & 0 \\
\hline \multirow[t]{3}{*}{ Salah El-din } & 1 & Festival & Sandy & + & 13 \\
\hline & 2 & Fortuna & Sandy & - & 0 \\
\hline & 3 & Florida & Sandy & - & 0 \\
\hline \multirow[t]{4}{*}{ AbdelmegedMoorsy } & 1 & Festival & Sandy & + & 12 \\
\hline & 2 & Fortuna & Sandy & + & 11 \\
\hline & 3 & Florida & Sandy & - & 0 \\
\hline & 4 & Winter Star & Sandy & + & 5 \\
\hline \multirow[t]{2}{*}{ Badr } & 1 & Florida & Sandy & + & 22 \\
\hline & 2 & Fortuna & Sandy & - & 0 \\
\hline Ali EbnAbyTaleb & 1 & 029 & Sandy & - & 0 \\
\hline AdelsalaamAref & 1 & Festival & Sandy & + & 17.5 \\
\hline El-Fateeh & 1 & Fortuna & Sandy & - & 0 \\
\hline Baghdad & 1 & Winter Star & Sandy & + & 15 \\
\hline \multirow[t]{2}{*}{ Abo Bakr el Sedek } & 1 & Festival & Sandy & + & 18 \\
\hline & 2 & 029 & Sandy & - & 0 \\
\hline \multirow[t]{2}{*}{ Center 2} & 1 & Festival & Sandy & + & 20 \\
\hline & 2 & Winter Star & Sandy & - & 0 \\
\hline Osman EbnAfan & 1 & 029 & Sandy & + & 8.7 \\
\hline El khartom & 1 & Winter Star & Sandy & + & 20 \\
\hline El khartom & 1 & Winter Star & Sandy & + & 20 \\
\hline \multirow[t]{2}{*}{ El magd } & 1 & Festival & Sandy & + & 28 \\
\hline & 2 & Fortuna & Sandy & - & 0 \\
\hline \multirow[t]{3}{*}{ Airport Area } & 1 & Festival & Sandy & + & 30 \\
\hline & 2 & Festival & Sandy & - & 0 \\
\hline & 3 & Florida & Sandy & - & 0 \\
\hline \multirow[t]{2}{*}{ Abdel hamedzedan } & 1 & Festival & Sandy & + & 30 \\
\hline & 2 & Winter Star & Sandy & - & 0 \\
\hline Ahmed Orabe & 1 & Winter Star & Sandy & + & 25 \\
\hline \multirow[t]{2}{*}{ Nabil El Waqad } & 1 & Fortuna & Sandy & + & 15 \\
\hline & 2 & 029 & Sandy & - & 0 \\
\hline \multirow[t]{3}{*}{ Khaled EbnElwaled } & 1 & Fortuna & Sandy & + & 15 \\
\hline & 2 & 029 & Sandy & - & 0 \\
\hline & 3 & Florida & Sandy & - & 0 \\
\hline Mobarak & 1 & Florida & Sandy & + & 10 \\
\hline
\end{tabular}


Table 3. Survey of charcoal rot disease in Kom Hamada District, El-Behira Governorate.

\begin{tabular}{lccccc}
\hline Location & No & Cultivar & Soil Type & DI & PDI \\
\hline Alkam & 1 & Festival & Clay & + & 15 \\
& 2 & Fortuna & Clay & - & 0 \\
\hline Maghnen & 1 & Festival & Clay & + & 25 \\
\hline Komsherek & 1 & Festival & Clay & + & 30 \\
& 2 & Fortuna & Clay & - & 0 \\
\hline Abo el khawey & 1 & Festival & Clay & + & 30 \\
& 2 & Winter Star & Clay & - & 0 \\
& 3 & Fortuna & Sandy & - & 0 \\
& 4 & Florida & Sandy & - & 0 \\
\hline El Tayarya & 1 & 029 & Sandy & + & 10 \\
& 2 & Fortuna & Sandy & - & 0 \\
\hline El Tayary El balad & 1 & Festival & Sandy & - & 15 \\
& 2 & Winter Star & Sandy & - & 0 \\
& 3 & Florida & Sandy & - & 0 \\
\hline KafrZyada & 1 & Festival & Clay & + & 22 \\
\hline EL Zafrn & 1 & Festival & Clay & + & 17 \\
& 2 & Winter Star & Clay & - & 0 \\
\hline Waqed & 1 & Winter Star & Clay & + & 22 \\
\hline Manshit Abo Raya & 1 & Festival & Sandy & + & 20 \\
\hline DI Disease & 2 & Sabsentand & \\
\hline
\end{tabular}

DI=Disease incidence. + = Symptoms present and positive infection, - = Symptoms absent and Negative infection. PDI

$=$ Percentage of Disease Incidence.

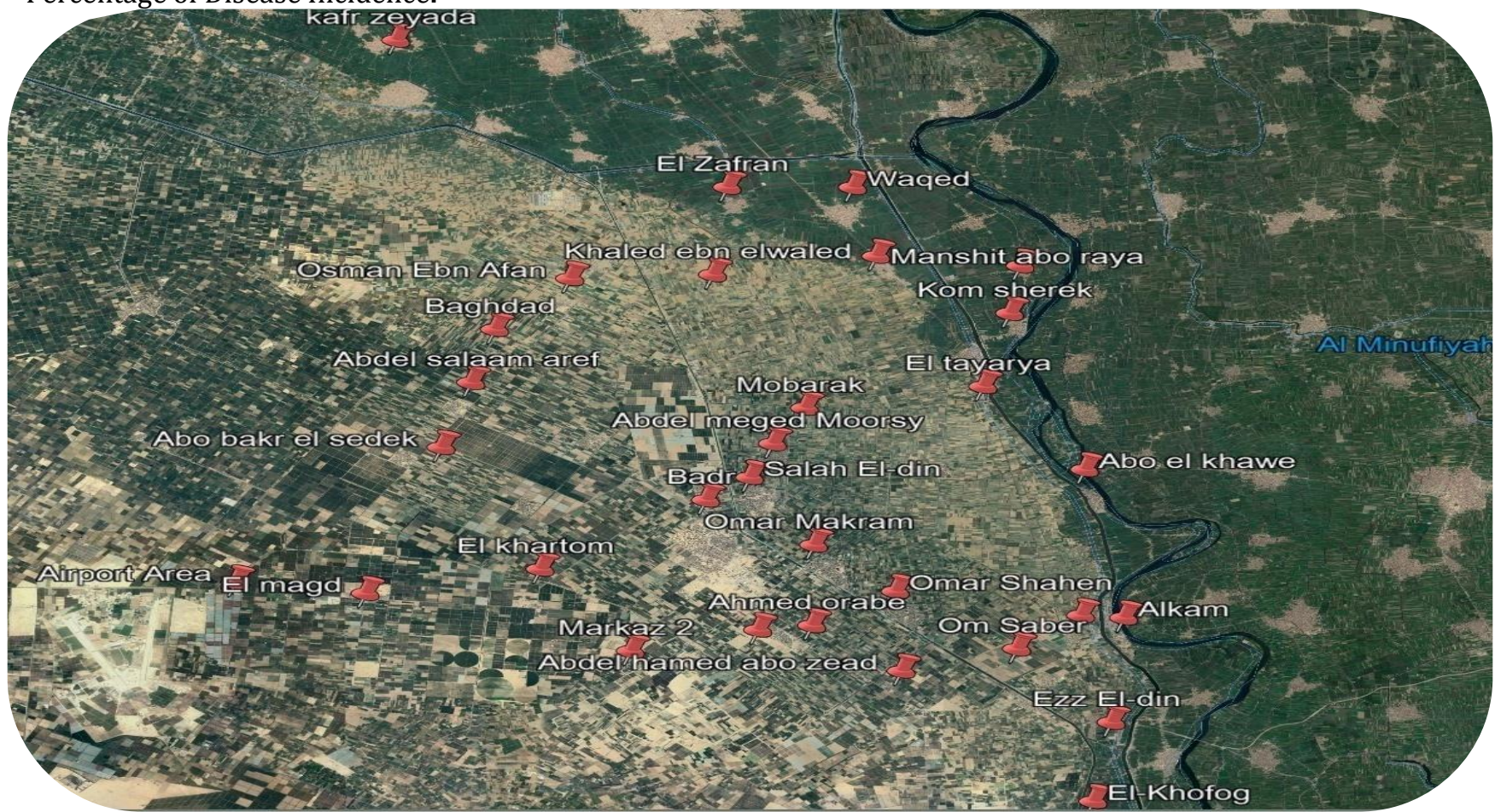

Figure 2. Occurrence of $M$. phaseolina in strawberry production locations in different regions in El-Beheira Governorate

Isolation of $M$. phaseolina from infected strawberry plants: Data presented in (Table 4) indicated that $M$. phaseolina was the main isolated pathogen from charcoal rot infected plant materials from strawberry plants of different growing areas. Other isolated pathogenic and non-pathogenic fungi were discarded according to the microscopic examination. Seven isolates of M.phaseolina coded as M1-M7 were isolated from seven grown locaties in El-Behira governorate. The fungus was isolated from different strawberry cultivars, 
Festival cultivar was the most dominant one followed by Winter star, Florida and 029 cultivars.

Table 4. Isolates of M. phaseolina isolated from different area in El-Behira governorate from different strawberry cultivars.

\begin{tabular}{ccccc}
\hline Isolate & code & District & Location & Cultivar \\
\hline 1 & M 1 & Badr & Om saber & Festival \\
2 & M 2 & Kom Hamada & KomSherek & Festival \\
3 & M 3 & Badr & AbdelmegedMorsy & Festival \\
4 & M 4 & Kom Hamada & Waqed & Winter star \\
5 & M 5 & Badr & Center 2 & Festival \\
6 & M 6 & Badr & Airport Area & 029 \\
7 & M7 & Badr & Mubarak & Florida \\
\hline
\end{tabular}

Pathogenicity test: Data presented indicate that, significant differences were recorded between all tested isolates in disease parameters and in their ability to cause plant death on the tested cultivar as compared to control treatment.

The virulence of the tested M. phaseolina isolates was significantly varied in inducing charcoal rot disease severity. The most pathogenic Isolates were M3 and M4 as they produced the highest percentage of infected plants (100\%)followed by isolates M2 and M6 by91.6 $\%$,while the isolate M5 was the least pathogenicas illustrated in (Figure 3). Control plants remained symptomless. According to pointed out the results the selected isolates could be separated in different groups concerning to its pathogenicity i.e.:Moderately pathogenic isolates (M5) highly pathogenic isolates (M1and M7), aggressive isolates (M2and M3) and destructive isolates (M3 and M4). Macrophomina phaseolina was re-isolated from all plants showing symptoms.

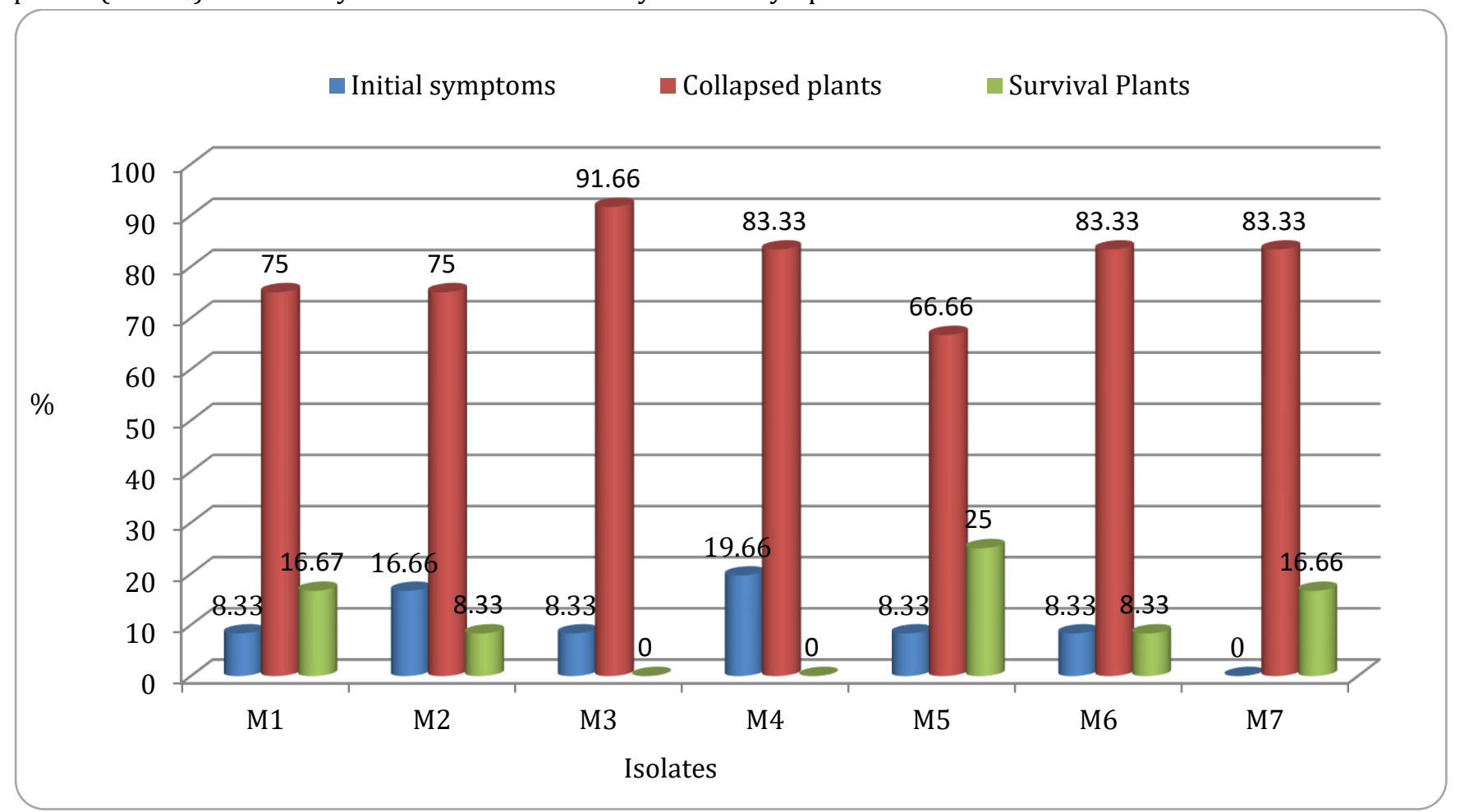

Figure 3. Pathogenicity test of M. phaseolina fungi on strawberry plant CV. Festival under greenhouse conditions.

Susceptibility of some strawberry cultivars to $\boldsymbol{M}$. between the different cultivars. The most susceptible phaseolina.: Macrophomina phaseolina isolate M3 in cultivar with 95\%of disease severity followed by relation to strawberry cultivars i.e. festival, winter star, 029 and Fortuna was evaluated. Results were concluded that there was a significant difference Winter Star by $80 \%$ and Fortuna by $65 \%$. The least susceptible one to charcoal rot was $029(30 \%)$ as showed in (Figure 4). 


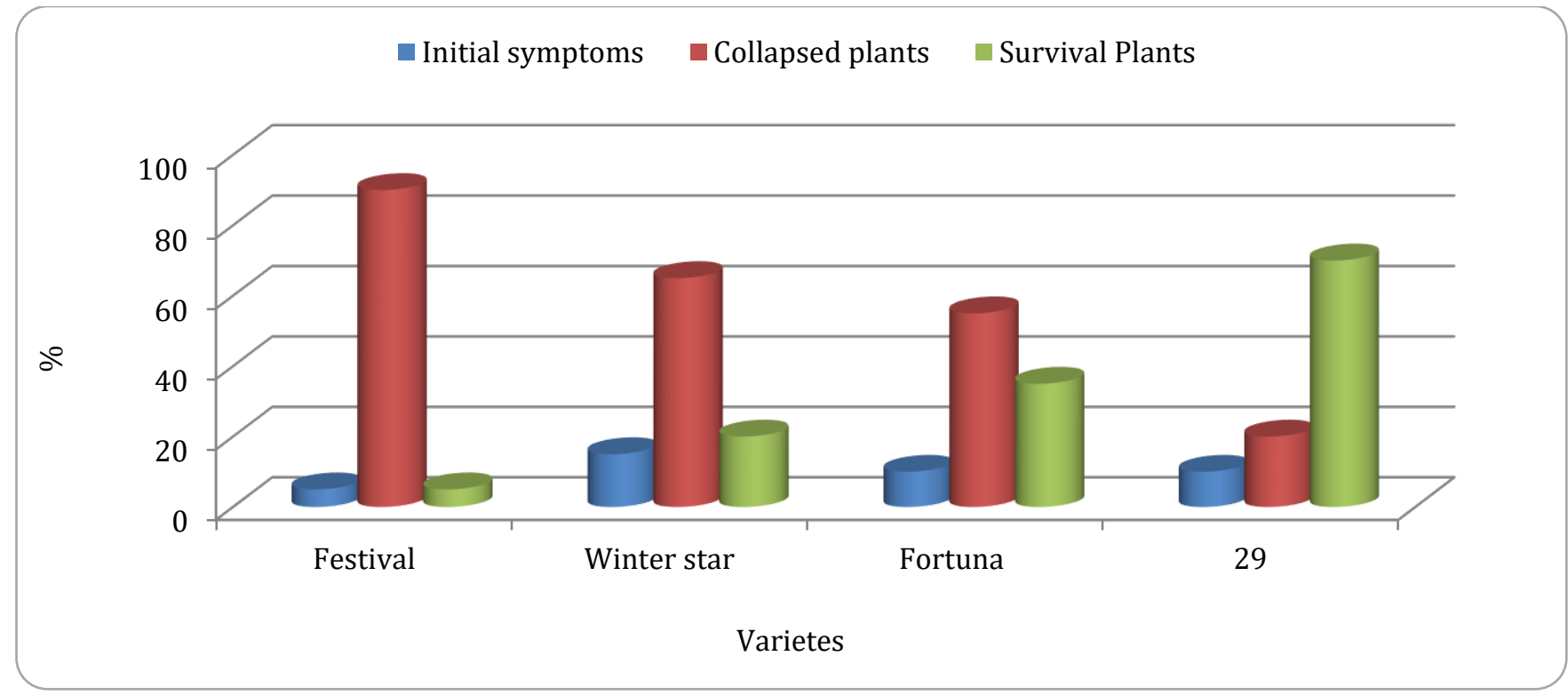

Figure 4. Susceptibility of strawberry varieties to M. phaseolina under greenhouse conditions.

Chemical control: In vitro Results presented in (Table $\mathrm{ppm}$ of concentration, Sendo gave the highest 5) showed significant effect of the used fungicides in reducing the mycelia radial growth of $M$. phaseolina comparing with untreated control. Data clarify that $M$. phaseolina varied in their sensitivity against the fungicide tested (Sendo, Moncut, Sandcure, Rhizolex-T, Ridomil gold plus). In general, toxicity was gradually increased by increasing in concentration of the fungicide. The toxic effect on fungal mycelial growthwas observed at 5 ppm with Rhizolex-T and then with Sendo, Moncut, Sandcure while Ridomil gold plus was not effective at this concentration. At $10 \mathrm{ppm}$ a clear inhibition of mycelialradial growth was found with Sendo, Sandcure, Rhizolex-T, then with Moncut, while Ridomil gold plus did not show any toxic effect.At 50 percentage of mycelial growth inhibition (87.23\%) followed by Rhizolex-T as it inhibit the mycelium growth by $75.5 \%$ while, Ridomil gold plus did not show any inhibition effect. At a concentration of $100 \mathrm{ppm}$ all the fungicides used showed inhibition of $M$. phaseolina mycelial growth but at different rates, $91.95 \%$ was recorded with Sendo and $91.12 \%$ with Rhizolex-T but the least effect was recorded with Ridomil gold plus by $31.67 \%$ of mycelial growth inhibition.In the plates treated with $200 \mathrm{ppm}$ of the tested fungicides, Rhizolex$\mathrm{T}$ gave the highest inhibition rate by $96.67 \%$,followed by Sendo and Sandcur by 95.96 and $95.00 \%$, respectively, while Ridomil gold plus gave the least inhibition rate by 43.06\%as show in (Figure 5).

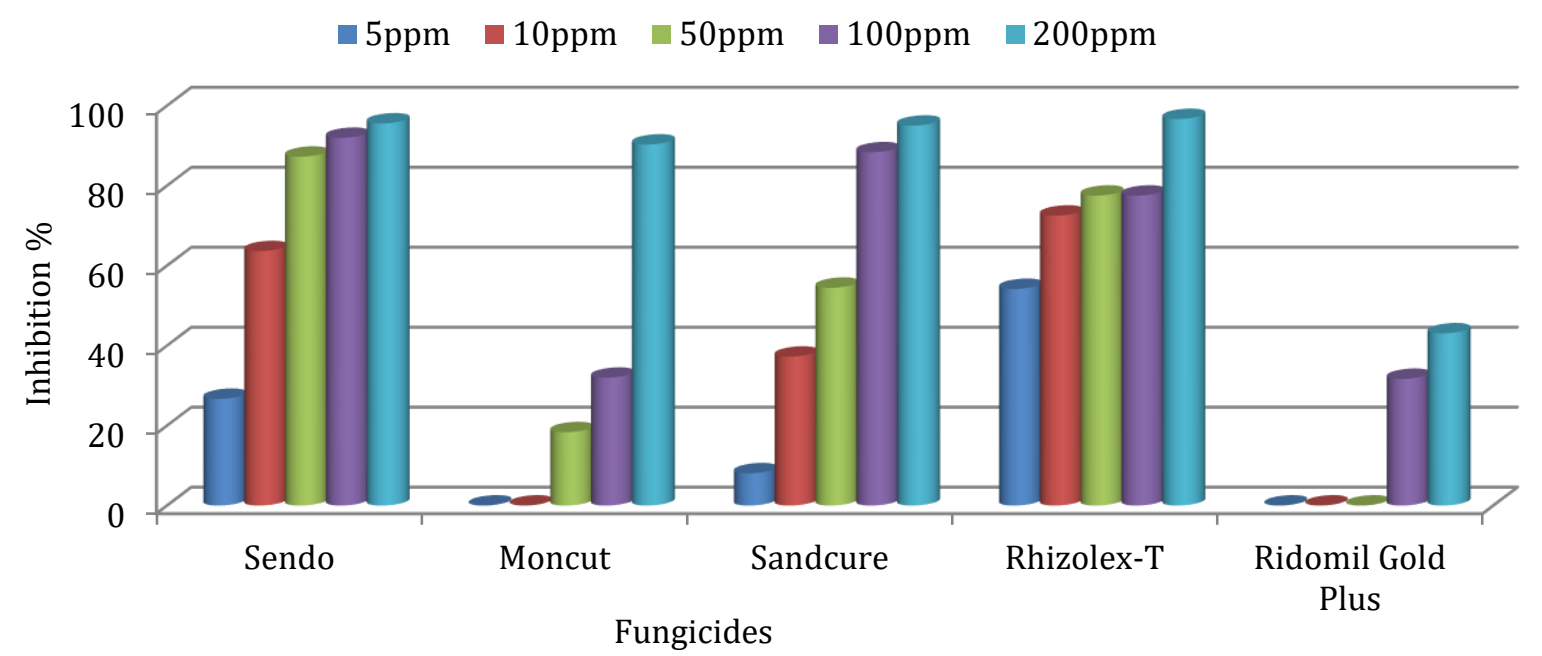

Figure 5. Inhibition percentage of M. phaseolina mycelium growth by different concentrations of different fungicides. 
Table 5. Effect of five fungicides with different concentration on the growth of M. phaseolinain vitro.

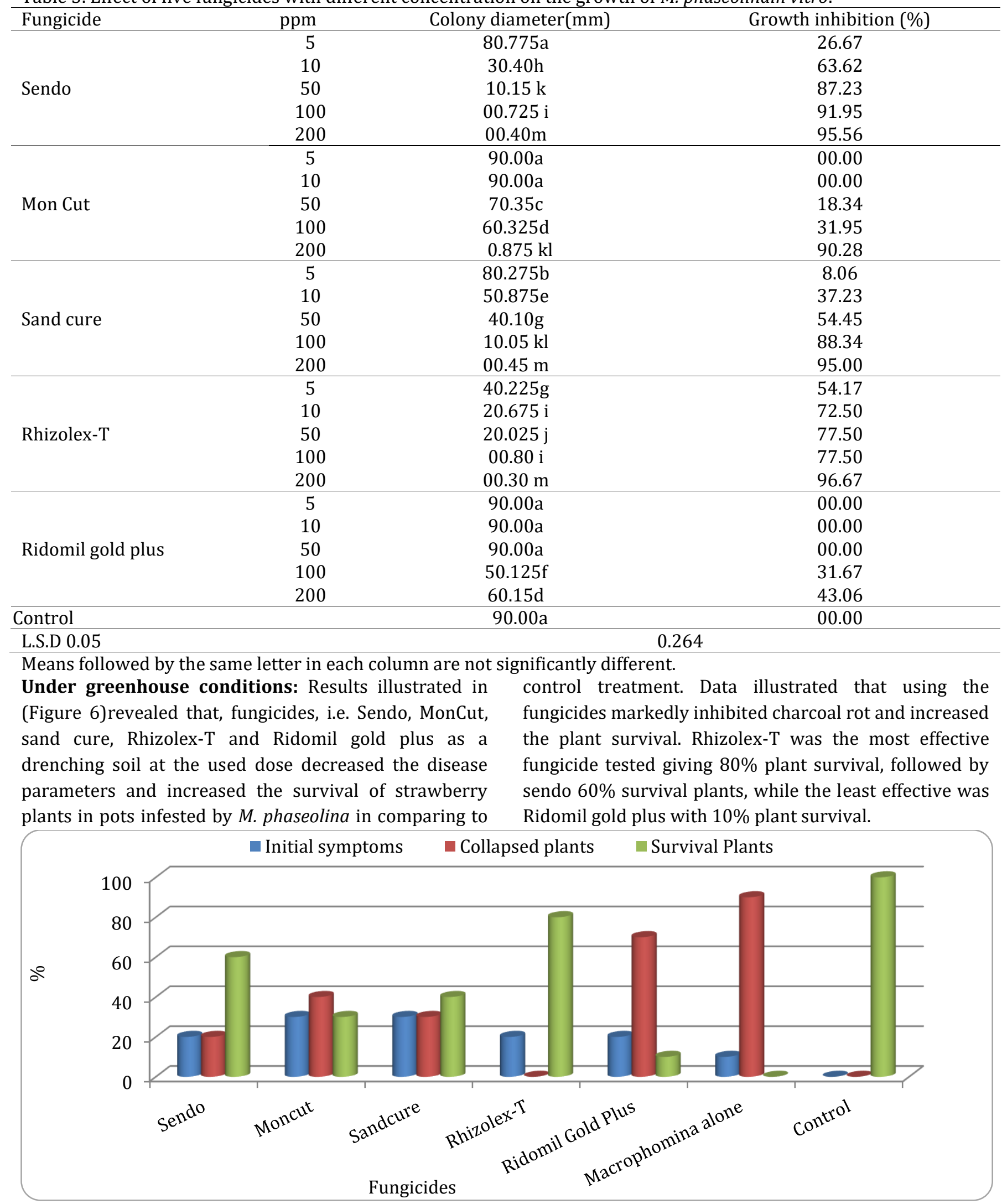

Figure 6. Effect of some fungicides on the incidence of Initial symptoms and Collapse of Plant. 


\section{DISCUSSION}

Charcoal-rot disease caused by M. phaseolina, is one of the most destructive soil borne diseases of strawberry all over the world. Throughout the survey, incidence of charcoal rot was reported in the strawberry fields and the incidence was varies in production districts. The disease development generally may be enhanced by some combination of heat stress, irrigation water deficiency, light-textured soil, or the stress associated with host reproduction (Mihail, 1989).High temperatures seasons create a suitable condition for $M$. phaseolina development and multiplication, especially in the intensive agricultural system and this confirms the presence of $\mathrm{M}$. phaseolina during late spring/early summer when the temperatures almost above $30^{\circ} \mathrm{C}$ (Fang et al., 2011). In the present study M. phaseolina was isolated from the collected strawberry samples and the aggressiveness of the fungus isolates in commercial strawberry cultivars showed significant differences among all tested isolates in disease severity. The most virulent Isolates were M3 and M4 and the last one was M5. We were grouping the isolates according to isolates pathogenicity to moderately pathogenic, highly pathogenic, severe and destructive isolates. The variation among M. phaseolina isolates pathogenicity can be referred to the high genetic diversity and the diversity in the genotypes can refer to a phenotypes differences between these isolates, and therefore affect their virulence (Sánchez et al., 2016).

Our results revealed that the tested strawberry cultivars differed in their susceptibility to the infection with, $M$. phaseolina. Festival was the most susceptibile to charcoal rot followed by Winter Star and Fortuna while 029was the least susceptible one. Similar results previously obtained by Fang et al., (2011), who found that cultivar Festival was susceptible to M. phaseolina. The varieties of strawberry show different susceptibility to crown and root rot caused by M. phaseolina affected by differed in their factors such as, differences in the pathogenicity of the fungus isolate and plant genotype.(Avilés, et al.,2008; S'anchez et al., 2016).

Machrophomina phaseolina showed various sensitivity to the tested chemicals fungicide. All chemical fungicides inhibit the growth of M. phaseolina in vitro but the rate of inhibition was different among the selected fungicides. The fungus genetics can affect its sensitivity toward the fungicides as a sensitive or insensitive to a chemical molecule. The sensitivity means fungi toxicity but insensitivity means as no fungal toxicity (Reis et al. 2010). Also the differences in the chemical group and the active ingredient of the used fungicides are much supported for the potential variation.

The obtained results concerning the efficacy of the tested fungicides against the fungus $M$. phaseolina in vitro and in vivo are in the same line with previous researchers (Khalikar et al., 2011; Thombre and Thombre, 2018). Our findings are in agreement with those obtained by Tonin et al., (2013) and Parmar et al., (2017) as they found that carbendazim was the most efficient fungicide in inhibition the mycelia radial growth of M. phaseolina, while the fungus was insensitive to the active ingredients of Metalaxyl. It was acceptable that not all chemicals are causing toxicity to fungi and therefore there is no fungicide control all fungi (Reis et al., 2010).

\section{CONCLUSION}

It is urgently important to know the distribution of $M$. phaseolina in the grown strawberry areas. Moreover, knowledge about the nature of strawberry commercial varieties susceptibility for use in wide cultivation area and looking forward to find new more resistant varieties to M. phaseolina. Exploration of the effective fungicides chemical ingredient will provide information that can be involved in future planning programs for charcoal rot disease management.

\section{REFERENCES}

Angelini, R. and W. Faedi. 2010. Malattie e fisiopatie. ART. La Fragola, Bologna, Italy: 228-246.

Avilés, M., S. Castillo, C. Borrero, M. L. Castillo, T. ZeaBonilla and R. M. Pérez-Jiménez. 2009. Response of strawberry cultivvars: 'Camarosa', 'Candonga' and 'Ventana' to inoculation with isolates of Macrophomina pahseolina. Acta Horticulturae: 291-294.

Avilés, M., S. Castillo, J. Bascon, T. Zea-Bonilla, P. M. Martín-Sánchez and R. M. Pérez-Jiménez. 2008. First report of Macrophomina phaseolina causing crown and root rot of strawberry in Spain. Plant Pathology, 57: 382-382.

Baino, O. M., S. M. Salazar, A. C. Ramallo and D. S. Kirschbaum. 2011. First Report of Macrophomina phaseolina Causing Strawberry Crown and Root Rot in Northwestern Argentina. Plant Disease, 95: 1477-1477.

Baird, R. E., C. E. Watson and M. Scruggs. 2003. Relative Longevity of Macrophomina phaseolina and 
Associated Mycobiota on Residual Soybean Roots in Soil. Plant Disease, 87: 563-566.

Benlioglu, S., A. Yildiz and T. Doken. 2004. Studies to Determine the Causal Agents of Soil-borne Fungal Diseases of Strawberries in Aydin and to Control them by Soil Disinfestation. Journal of Phytopathology, 152: 509-513.

Carter, M. 2016. Investigating novel approaches for the integrated control of the soilborne strawberry pathogens Macrophomina phaseolina and Fusarium oxysporum f. sp. fragariae. A Thesis presented to the Faculty of California Polytechnic State University.

Chamorro, M., P. Domínguez, J. J. Medina, L. Miranda, C. Soria, F. Romero, J. M. López Aranda, O. Daugovish, J. Mertely and B. De los Santos. 2015. Assessment of chemical and biosolarization treatments for the control of Macrophomina phaseolina in strawberries. Scientia Horticulturae, 192: 361368.

Cioffi, R. 2003. Angelini, Costanzo, Oxford Art Online. Oxford University Press.

Dhingra, O. D. and J. B. Sinclair. 1977. An annotated bibliography of Macrophomina phaseolina 19051975. An annotated bibliography of Macrophomina phaseolina 1905-1975.

Dhingra, O. D. and J. B. Sinclair. 1978. "Biology and Pathology of Macrophimina phaseolina. Australasian Plant Pathology, 7: 25-25.

Fang, X. L., D. Phillips, H. Li, K. Sivasithamparam and M. J. Barbetti. 2011. Severity of crown and root diseases of strawberry and associated fungal and oomycete pathogens in Western Australia. Australasian Plant Pathology, 40: 109-119.

Fang, X., D. Phillips, H. Li, K. Sivasithamparam and M. J. Barbetti. 2011. Comparisons of virulence of pathogens associated with crown and root diseases of strawberry in Western Australia with special reference to the effect of temperature. Scientia Horticulturae, 131: 39-48.

Food and Agriculture Organization of the United Nations. 2016.

Gammon, N. 1972. Epstein, Emanuel. Mineral nutrition of plants: Principles and perspectives. New York: John Wiley \& Sons, Inc., 1972 (412 pages) \$10.95. Science Education, 56: 569-570.

Golzar, H., D. Phillips and S. Mack. 2007. Occurrence of strawberry root and crown rot in Western Australia. Australasian Plant Disease Notes, 2: 145.

Hutton, D. G., A. O. Gomez and S. W. Mattner. 2013. Macrophomina phaseolina and Its Association with Strawberry Crown Rot in Australia. International Journal of Fruit Science, 13: 149-155.

Khalikar, P., V. Gholve and A. Adsul. 2011. In vitro management of Macrophomina phaseolina by chemicals. International Journal of Plant Protection, 4: 201-203.

Koike, S. T., T. R. Gordon, O. Daugovish, H. Ajwa, M. Bolda and K. Subbarao. 2013. Recent developments on strawberry plant collapse problems in california caused by Fusarium and Macrophomina. International Journal of Fruit Science, 13: 76-83.

Mertely, J., T. Seijo and N. Peres. 2005. First report of Macrophomina phaseolina causing a crown rot of strawberry in Florida. Plant Disease, 89: 434-434.

Mihail, J. D. 1989. Macrophomina phaseolina: spatiotemporal dynamics of inoculum and disease in a highly susceptible crop. Phytopathology, 79: 848.

Parmar, H., H. Kapadiya and C. Bhaliya. 2017. Efficacy of different fungicides against Macrophomina phaseolina (Tassi) Goid causing castor root rot. International Journal of Communication Systems, 5: 1807-1809.

Porras, M., C. Barrau, F. T. Arroyo, B. Santos, C. Blanco and F. Romero. 2007. Reduction of Phytophthora cactorumin strawberry fields by Trichoderma spp. and soil solarization. Plant Disease, 91: 142-146.

Reis, E., A. Reis and M. Carmona. 2010. Manual de fungicidas: guia para o controle químico de doenças de plantas. Passo Fundo: UPF.

Sánchez, S., J. L. Henríquez, L. A. Urcola, A. Scott and M. Gambardella. 2016. Susceptibility of strawberry cultivars to root and crown rot caused by Macrophomina phaseolina. Journal of Berry Research, 6: 345-354.

Sharifi, K. and M. Mahdavi. 2012. First report of strawberry crown and root rot caused by Macrophomina phaseolina in Iran. Iranian Journal of Plant Pathology, 47.

Su, G., S. O. Suh, R. W. Schneider and J. S. Russin. 2001. Host specialization in the charcoal rot fungus, Macrophomina phaseolina. Phytopathology, 91: 120-126.

Thombre, B. and 0. Kohire. 2018. Integrated 
management of Macrophomina blight of mungbean (Vigna radiata L.) caused by Macrophomina phaseolina (Tassi) Goid. Indian Phytopathology, 71: 423-429.

Tjamos, E., P. Antoniou, A. Skourtaniotis, E. Kikrilis and S. Tjamos. 2006. Impermeable plastics and methyl bromide alternatives in controlling soil borne fungal pathogens of strawberries in Greece. Proceedings 12th Congress Mediterranean Phytopathological Union. pp. 255-257.

Tonin, R. F. B., A. Avozani, A. L. D. Danelli, E. M. Reis, S. M.
Zoldan and F. R. Garcés-Fiallos. 2013. In vitro mycelial sensitivity of Macrophomina phaseolina to fungicides. Pesquisa Agropecuária Tropical, 43: 460-466.

Watanabe, T., 2010. Pictorial atlas of soil and seed fungi: morphologies of cultured fungi and key to species. CRC press..

Zveibil, A., N. Mor, N. Gnayem and S. Freeman. 2012. Survival, host-pathogen interaction, and management of Macrophomina phaseolina on strawberry in Israel. Plant Disease, 96: 265-272. 